\title{
ZNACZENIE WYROKU W SPRAWIE TARAKHEL PRZECIWKO SZWAJCARII WOBEC PROBLEMU NAPŁYWU OSÓB POSZUKUJĄCYCH OCHRONY MIĘDZYNARODOWEJ DO REPUBLIKI WŁOSKIEJ*
}

DOI: http://dx.doi.org/10.12775/TSP-W.2015.004

\section{WPROWADZENIE}

Celem niniejszego artykułu jest analiza wyroku Europejskiego Trybunału Praw Człowieka (dalej: ETPCZ) z 4 listopada 2014 r. w sprawie Tarakhel przeciwko Szwajcarii, w którym Trybunał uznał, że zawrócenie migrantów ubiegających się o status uchodźcy ze Szwajcarii do Włoch, jako państwa właściwego do rozpatrzenia ich wniosku statusowego, może naruszyć gwarancje z art. 3 i 8 Europejskiej konwencji o ochronie praw człowieka i podstawowych wolności (dalej: EKPCZ) ${ }^{1}$. Uzasadniając wyrok, Trybunał oparł się w szczególności na argumentach dotyczących problemów, z jakimi boryka się Republika Włoska w organizacji systemu azylowego, w tym funkcjonowaniu ośrodków recepcyjnych. Tym samym Włochy stały się kolejnym państwem, które zdaniem Trybunału, nie zapewnia warunków godnego i humanitarnego rozpatrzenia wniosków o status uchodźcy składanych przez obywateli państw trzecich. Przełomowym wyrokiem w sprawach tzw. dublińskich był wyrok w sprawie M.S.S

* Artykuł prezentuje stan prawny na 1.05.2015 r.

1 Wyrok Europejskiego Trybunału Praw Człowieka z 4.11.2014 r. w sprawie Tarakhel przeciwko Szwajcarii, skarga nr 29217/12. 
przeciwko Belgii i Grecji ${ }^{2}$, kiedy to ETPCZ uznał, że zawracanie migrantów do Grecji jako kraju pierwszego wjazdu do Unii Europejskiej narusza zakaz nieludzkiego traktowania zagwarantowany $w$ art. 3 Konwencji ${ }^{3}$. Podobny pogląd o funkcjonowaniu systemu azylowego w Grecji wyraził Trybunał Sprawiedliwości Unii Europejskiej (dalej: TSUE) w sprawie N. S. przeciwko Secretary of State ${ }^{4}$.

Wyrok dotyczący Republiki Włoskiej jest o tyle nietypowy, że po pierwsze, do zawrócenia migrantów nie doszło, w związku z czym skarżący zaskarżył jedynie decyzję o nakazie powrotu wydaną przez władze Szwajcarii. Po drugie, wart odnotowania jest indywidualny charakter rozpatrzenia sprawy (mimo oczywistej dogłębnej analizy uchybień w funkcjonowaniu systemu azylowego w Italii), ze szczególnym naciskiem położonym na sytuację rodzinną skarżącego oraz dobitnie wyrażone częściowo zdanie odrębne przez sędziów Casadevalla, Berro-Lefevre oraz Jaderbloma ${ }^{5}$. Po trzecie, orzeczenie stoi w opozycji do dotychczasowej linii orzeczniczej - w sprawie Mohammed Hussein przeciwko Holandii i Republice Włoskiej ${ }^{6}$ skład orzekający uznał, że skarżący nie wykazali, iż w przypadku zawrócenia ich do Włoch istniałoby ryzyko naruszenia art. 3 Konwencji oraz że nie można stwierdzić istnienia systemowych uchybień w organizacji włoskiego systemu azylowego.

Warto wreszcie podkreślić, że wyrok w sprawie Tarakhel ma ogromne znaczenie w obecnej sytuacji migracyjnej Włoch. Jego sentencja i analiza problemów włoskiego systemu azylowego może stać się istotną wytyczną dla prowadzenia przez Unię Europejską polityki azylowej w sytuacji znaczącego wzrostu napływu migrantów nieregularnych na terytorium Półwyspu Apenińskiego ${ }^{7}$.

Zgodnie z danymi prezentowanymi przez Komisję Europejską i opracowanymi przez Frontex, w 2014 r. do Włoch dostało się poprzez wody Morza Śródziemnego 170816 osób (w porównaniu z 45298 osobami w 2013 r.) ${ }^{8}$. Wy-

2 Wyrok Europejskiego Trybunału Praw Człowieka z 21.01.2011 r. w sprawie M.S.S. przeciwko Belgii i Grecji, skarga nr 30696/09.

${ }^{3}$ Konwencja o ochronie praw człowieka i podstawowych wolności, 4.11 .1950 r., Dz.U. 1993 61.284 ze zm. Artykuł 3 Konwencji dotyczy ochrony przed nieludzkim traktowaniem, art. 8 zaś prawa do poszanowania życia prywatnego i rodzinnego.

${ }^{4}$ Wyrok TSUE z 21.12.2011 r. N.S. v Secretary of State for Home Department, C - 411/10 i C $-493 / 10$.

${ }^{5}$ Zob. s. 53 pełnej wersji wyroku.

${ }^{6}$ Wyrok Europejskiego Trybunału Praw Człowieka z 18.04.2013 r. w sprawie Mohammed Hussein przeciwko Holandii i Republice Włoskiej, skarga nr 27725/10.

${ }^{7}$ Raport roczny Amnesty International 2014/2015. Sytuacja Praw Człowieka na Świecie, s. 202; raport dostępny na stronie www.amnesty.org (dostęp: 11.05.2015).

${ }^{8}$ European Commision Fact Sheet, Questions and Answers: Smuggling of Migrants in Eu- 
darzenia 19 czerwca 2015 r., gdy w Cieśninie Sycylijskiej zatonął statek wiozący ok. 700 migrantów ${ }^{9}$, stawiają pod znakiem zapytania skuteczność prowadzonych dotychczas działań w obrębie ochrony granic zewnętrznych Unii z jednej strony oraz realizacji zasady solidarności pomiędzy państwami członkowskimi $\mathrm{z}$ drugiej.

\section{WSPÓLNY EUROPEJSKI SYSTEM AZYLOWY I ROZPORZĄDZENIE „DUBLIŃSKIE”}

Na mocy postanowień traktatu amsterdamskiego utworzona została Przestrzeń Wolności, Bezpieczeństwa i Sprawiedliwości ${ }^{10}$, a w jej ramach Wspólna Europejska Polityka Azylowa. Choć podstawą dla ochrony osób poszukujących azylu była w państwach europejskich konwencja genewska ${ }^{11}$, to państwa członkowskie zdecydowały się przyjąć wspólne standardy odnośnie do udzielanej ochrony, procedur azylowych oraz organizacji ośrodków recepcyjnych. Służyło temu przyjęcie pakietu dyrektyw, które zostały w ostatnim czasie znowelizowane - są to dyrektywa tzw. kwalifikacyjna, proceduralna i recepcyjna ${ }^{12}$.

rope and the EU response, Brussels, 13 January 2015, dane dostępne na stronie: http://europa.eu/ rapid/press-release_MEMO-15-3261_en.htm (dostęp: 11.05.2015).

${ }_{9}$ Zob. m.in. Ennesima e gravissima tragedia nel Mediterraneo. Amnesty International Italia: l'Europa intervenga di fronte a questa crisi umanitaria, informacja dostępna na stronie: http:// www.amnesty.it/Ennesima-gravissima-tragedia-nel-Mediterraneo-Europa-intervenga-di-fronte-aquesta-crisi-umanitaria (dostęp: 11.05.2015).

${ }^{10}$ Co istotne, wraz z wejściem w życie TA, do systemu prawnego Unii włączony został też dorobek Schengen, a co za tym idzie kwestie związane z zarządzaniem i ochroną granic zewnętrznych również stały się przedmiotem zainteresowania UE. Więcej na ten temat zob. SzACHoń-Pszenny A., Acquis Schengen a granice wewnętrzne i zewnętrzne Unii Europejskiej, Poznań 2011.

${ }^{11}$ Konwencja dotycząca statusu uchodźców, sporządzona w Genewie dnia 28 lipca 1951 r., Dz.U. 1991119.515.

12 Dyrektywa Parlamentu Europejskiego i Rady 2013/32/UE z dnia 26 czerwca 2013 r. w sprawie wspólnych procedur udzielania i cofania ochrony międzynarodowej, Dz.Urz. UE z 29.06.2013, L 180/60 (akt wchodzi w życie 21.07.2015 r.), Dyrektywa Parlamentu Europejskiego i Rady 2013/33/UE z dnia 26 czerwca 2013 r. w sprawie ustanowienia norm dotyczących przyjmowania wnioskodawców ubiegających się o ochronę międzynarodową (wersja przekształcona) Dz.Urz. UE 29.06.2013 L 180/96. (mająca zastosowanie od 21.07.2015 r.)., Dyrektywa Parlamentu Europejskiego i Rady 2011/95/UE z dnia 13 grudnia 2011 r. w sprawie norm dotyczących kwalifikowania obywateli państw trzecich lub bezpaństwowców jako beneficjentów ochrony międzynarodowej, jednolitego statusu uchodźców lub osób kwalifikujących się do otrzymania ochrony uzupełniającej oraz zakresu udzielanej ochrony (wersja przekształcona), Dz.Urz. UE L 337/9 z 20.12.2011, (mająca zastosowanie od 21.12.2013 r.). 
Aby zapewnić przejrzystość systemu udzielania ochrony przez państwa europejskie, wprowadzone zostały również na poziomie UE regulacje pozwalające określić państwo odpowiedzialne za rozpatrzenie wniosku azylowego w przypadku, gdy cudzoziemiec złożył kilka takich wniosków w kilku państwach członkowskich. Pierwszym tego typu aktem było tzw. rozporządzenie Dublin II $^{13}$, obowiązujące obecnie w wersji zmienionej jako tzw. rozporządzenie Dublin III przyjęte 23 czerwca 2013 r. ${ }^{14}$ Rozporządzenie reguluje hierarchiczne kryteria uznania państwa odpowiedzialnego za rozpatrzenie wniosku - zgodnie $\mathrm{z}$ jego art. 7 „Państwo członkowskie odpowiedzialne zgodnie z kryteriami określonymi w niniejszym rozdziale ustalane jest na podstawie stanu istniejącego w chwili, w której wnioskodawca po raz pierwszy złożył wniosek o udzielenie ochrony międzynarodowej w państwie członkowskim" ${ }^{15}$. Co do zasady więc państwem odpowiedzialnym za rozpatrzenie wniosku jest również państwo pierwszego wjazdu na terytorium Unii Europejskiej. W sytuacji, gdy cudzoziemiec złoży kolejny raz wniosek w innym państwie członkowskim, powinien być co do zasady zawrócony, zgodnie z procedurą opisaną w rozporządzeniu, do państwa odpowiedzialnego, tj. państwa pierwszego wjazdu ${ }^{16}$. Wyjątkiem jest możliwość zastosowania przez państwo członkowskie tzw. klauzuli dyskrecjonalnej, zgodnie z którą „każde państwo członkowskie może zdecydować o rozpatrzeniu wniosku o udzielenie ochrony międzynarodowej wniesionego w tym państwie przez obywatela państwa trzeciego lub bezpaństwowca, nawet jeżeli za takie rozpatrzenie nie jest odpowiedzialne na podstawie kryteriów ustanowionych w niniejszym rozporządzeniu" ${ }^{17}$. Sprawy dublińskie i problem zawrócenia cudzoziemców do kraju pochodzenia stały się przedmiotem zainteresowania zarówno Europejskiego Trybunału Praw Człowieka, jak i Trybunału Sprawiedliwości Unii Europejskiej. Do najważniejszych orzeczeń należy zaliczyć wspomniany wyrok

${ }^{13}$ Rozporządzenie Rady (WE) nr 343/2003 z dnia 18 lutego 2003 r. ustanawiające kryteria i mechanizmy określania państwa członkowskiego właściwego dla rozpatrywania wniosku o azyl, wniesionego w jednym z państw członkowskich przez obywatela państwa trzeciego (Dz.Urz. UE L 50 z 25.2.2003 r.), obowiązywało do końca 2013 r.

14 Rozporządzenie Parlamentu Europejskiego i Rady (UE) nr 604/2013 z dnia 26 czerwca 2013 r. w sprawie ustanowienia kryteriów i mechanizmów ustalania państwa członkowskiego odpowiedzialnego za rozpatrzenie wniosku o udzielenie ochrony międzynarodowej złożonego w jednym z państw członkowskich przez obywatela państwa trzeciego lub bezpaństwowca (wersja przekształcona) Dz.Urz. UE L 180/31 z 29.06.2013 r.

15 Art. 7 rozporządzenia 604/2013.

16 Sekcja II, art., 21 i nn. rozporządzenia 604/2013.

17 Art. 17 rozporządzenia 604/2013. 
ETPCZ w sprawie MSS ${ }^{18}$ oraz orzeczenie w sprawie N.S. Trybunału Sprawiedliwości UE ${ }^{19}$.

Instrumentem umożliwiającym identyfikację osób poszukujących ochrony jest informatyczny system EURODAC, do którego wprowadzane są dane osób składających wniosek statusowy wraz z ich odciskami palców ${ }^{20}$. Istotną rolę w rozwoju i koordynacji działań z zakresu polityki azylowej przez państwa członkowskie odgrywa Europejski Urząd ds. Wsparcia w dziedzinie Azylu (European Support Office - EASO), który uzyskał zdolność operacyjną w $2011 \mathrm{r}$. i ma swoją siedzibę na Malcie ${ }^{21}$. W kontekście analizowanego tematu należy wspomnieć o szczególnym rodzaju aktywności EASO, jakim jest możliwość ustanawiania tzw. asylum suport teams (zespoły wsparcia w dziedzinie azylu, AST). Zgodnie z pkt 15 Preambuły rozporządzenia ustanawiającego Agencję, „Zespoły te powinny w szczególności służyć wiedzą fachową w zakresie usług tłumaczenia ustnego, informacjami o krajach pochodzenia oraz wiedzą w zakresie rozpatrywania spraw azylowych [...]"22. Zespoły wsparcia zostały skierowane do Włoch na mocy specjalnego planu wsparcia, który początkowo zakładał obecność EASO w Republice Włoskiej do końca 2014 r. ${ }^{23}$, ale ostatecznie czas

${ }^{18}$ Zob. również Factsheet "Dublin cases", January 2015, http://www.echr.coe.int/Documents/FS_Dublin_ENG.pdf. Na temat stosowania postanowień dublińskich we Włoszech zob. Il sistema Dublino e l'Italia, un rapporto in bilico, http://www.asgi.it/wp-content/uploads/2015/03/ Il-Sistema-Dublino-e-IItalia-un-rapporto-in-bilico.pdf (dostęp: 11.05.2015).

19 Wyrok TSUE z dnia 21 grudnia 2011 r. N.S. v Secretary of State for Home Department, C - 411/10 i C - 493/10.

${ }^{20}$ Rozporządzenie Parlamentu Europejskiego i Rady (UE) nr 603/2013 z dnia 26 czerwca 2013 r. w sprawie ustanowienia systemu Eurodac do porównywania odcisków palców w celu skutecznego stosowania rozporządzenia (UE) nr 604/2013 w sprawie ustanowienia kryteriów i mechanizmów ustalania państwa członkowskiego odpowiedzialnego za rozpatrzenie wniosku o udzielenie ochrony międzynarodowej złożonego w jednym z państw członkowskich przez obywatela państwa trzeciego lub bezpaństwowca oraz w sprawie występowania o porównanie $\mathrm{z}$ danymi Eurodac przez organy ścigania państw członkowskich i Europol na potrzeby ochrony porządku publicznego, oraz zmieniające rozporządzenie (UE) nr 1077/2011 ustanawiające Europejską Agencję ds. Zarządzania Operacyjnego Wielkoskalowymi Systemami Informatycznymi w Przestrzeni Wolności, Bezpieczeństwa i Sprawiedliwości (wersja przekształcona, wchodzi w życie 20.07.2015 r.), Dz.Urz. UE L 180/1 z 29.06.2013 r.

${ }^{21}$ Rozporządzenie Parlamentu Europejskiego i Rady (UE) nr 439/2010 z 19 maja 2010 r. w sprawie utworzenia Europejskiego Urzędu Wsparcia w dziedzinie Azylu, Dz.Urz. UE L 132/11 z 29.05.2010 r.

22 Pkt 15 Preambuły. Działania zespołów zostały uregulowane w rozdziale 3 rozporządzenia.

${ }^{23}$ EASO special suport plan to Italy, Malta $4^{\text {th }}$ June 2013, dokument dostępny na stronie: https://easo.europa.eu/wp-content/uploads/EASO-SPP-Italy-ELECTR-SIGNED.pdf (dostęp: 11.05.2015). 
trwania operacji został przedłożony i na mocy porozumienia z marca $2015 \mathrm{r}$. II faza planu potrwa do końca 2015 r. ${ }^{24}$

W związku z pojawiającymi się problemami zarządzania południowymi granicami zewnętrznymi wzrasta rola Agencji Frontex oraz wzmocnieniu uległa współpraca pomiędzy Agencjami PWBS ${ }^{25}$. Innym instrumentem wartym wskazania w kontekście omawianych zagadnień jest powstała w 2013 r. Task Force Mediterenian (TFM) - grupie tej przewodniczy Komisja, w jej działania zaś zaangażowane są państwa członkowskie, agencje UE oraz European External Action Service $^{26}$. TMF została ustanowiona na szczycie Rady Europejskiej w związku z tragedią i utonięciem migrantów w okolicy Lampedusy w październiku 2013 r., do jej głównych zadań zaś należy współpraca z państwami trzecimi, zwalczanie przemytu ludzi oraz wzmocnienie ochrony granic zewnętrznych.

\section{SYTUACJA MIGRACYJNA REPUBLIKI WŁOSKIEJ}

Z historycznego punktu widzenia Włochy były postrzegane zazwyczaj jako kraj emigracyjny. Mimo intensywnego rozwoju gospodarczego w XIX w., na początku XX stulecia emigracja Włochów była bardzo wysoka - tylko w 1913 r. dotyczyła ona 900000 osób, w latach 1901-1913 zaś z Italii wyjechało pra-

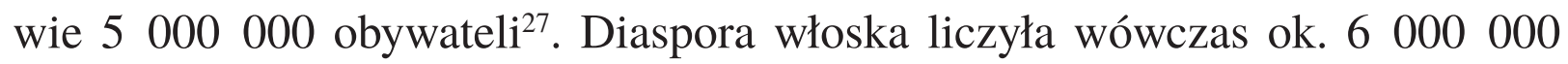
osób, zamieszkujących w Stanach Zjednoczonych, Argentynie, Brazylii, Francji, Niemczech i Szwajcariii ${ }^{28}$.

Po II wojnie światowej znacząca była migracja Włochów do innych państw Europejskiej Wspólnoty Gospodarczej, zwłaszcza do Niemiec ${ }^{29}$. Od lat 80. XX

${ }^{24}$ EASO special suport planto Italy phase II, Valetta Harbour and Rome, 11.03.2015; dokument dostępny na stronie: https://easo.europa.eu/wp-content/uploads/20150311-SSP-PHASE2-Italy-DEF.pdf (dostęp: 11.05.2015).

${ }_{25}$ Zob. https://easo.europa.eu/wp-content/uploads/20120926-Press-ReleaseEASOFRONTEX-Agreement.pdf, zob. również: Kosińska A. M. (2015), Działalność FRONTEX w kontekście ochrony problematyki ochrony praw migrantów nieregularnych $w$ Unii Europejskiej, w: A. Kuś, A. Kosińska, A. Szachoń-Pszenny (red.), Agencja FRONTEX w strefie Schengen. 10 lat doświadczeń, Lublin, s. 133.

${ }^{26}$ Communication from the Commision to the European Parliament and the Council on the work of Task Force Mediterranean, Brussels 4.12.2013, COM (2013), 869 final, http://register. consilium.europa.eu/doc/srv? $1=\mathrm{EN} \& \mathrm{t}=\mathrm{PDF} \& \mathrm{gc}=$ true $\& \mathrm{sc}=$ false $\& \mathrm{f}=\mathrm{ST} \% 2017398 \% 202013 \% 20$ INIT\&r=http $\% 3 \mathrm{~A} \% 2 \mathrm{~F} \% 2 \mathrm{Fregister}$.consilium.europa.eu $\% 2 \mathrm{Fpd} \% 2 \mathrm{Fen} \% 2 \mathrm{~F} 13 \% 2 \mathrm{Fst} 17 \% 2 \mathrm{~F}$ st17398.en13.pdf (dostęp: 11.05.2015).

27 Gierowski J.A. (2003), Historia Włoch, Wrocław, s. 460. Tak duży odsetek emigrantów w społeczeństwie wynikał m.in. z rosnącej liczby mieszkańców kraju - zob. ibid., s. 460.

28 Ibid.

29 Warto również wspomnieć o wewnętrznej migracji pracowniczej, która miała miejsce 
w. można odnotować tendencję napływu cudzoziemców na Półwysep Apeniński $^{30}$ - w latach 1981-1991 liczba obcokrajowców z zezwoleniem pobytowym uległa podwojeniu (z 300000 do 600 000) i wzrastała w kolejnych latach, aby osiągnąc $2400000 \mathrm{w} 2004$ r. ${ }^{31}$ Charakterystyczne dla współczesnych migracji do Włoch jest zjawisko nielegalnego przekraczania granicy czy też przekraczania terminu pobytu określonego $\mathrm{w}$ wizie, a następnie regularyzacja pobytu np. w drodze abolicji ${ }^{32}$.

Jak zostało wspomniane, Włochy jako państwo członkowskie UE uczestniczą w realizacji Wspólnej Europejskiej Polityki Azylowej oraz polityki migracyjnej. Według danych Europejskiej Sieci Migracyjnej, w latach 2011-2013 liczba migrantów pozostawała w miarę stabilna i wynosiła z końcem $2013 \mathrm{r}$. $3100000 \mathrm{osób}^{33}$. Z danych IDOS wynika, że cudzoziemców (w tym obywateli UE) było w 2013 r. we Włoszech prawie 5000000 i stanowili tym samym 8,1\% populacji ${ }^{34}$. Największa liczba cudzoziemców zamieszkuje regiony północne Lombardię, Emilię - Romanię i Veneto ${ }^{35}$

Pod względem narodowości wśród rezydentów dominowali Albańczycy, Marokańczycy, Chińczycy, Ukraińcy oraz Filipińczycy ${ }^{36}$. W 2013 r. stwierdzono nieregularny pobyt prawie 24000 osób, którym wydano decyzje zobowiązaniowe do powrotu. Do kraju pochodzenia wróciło jednak zaledwie niecałe 7000

w tym okresie, a mianowicie o przepływie pracowników z terenów południowych do bardziej uprzemysłowionych okręgów północnych, zwłaszcza w okolicach Mediolanu, Turynu i Genui. Castles S., Miler M.J. (2009), The Age of Migration, New York, s. 100 i 101.

${ }^{30}$ Imigracja związana była również ze zmniejszeniem się liczby urodzeń, a tym samym z obecnymi problemami demograficznymi Włoch - zob. FAKiolas R. (2010), Italy and Greece: from emigrants to immigrants, w: R. Cohen (ed.), The Cambridge Survey on World Migration, Cambridge University Press, s. 313.

31 Castles S., Miler M.J. (2009), op. cit., s. 111. Najliczniejszą grupę stanowili wówczas Rumunii.

32 Ibid. W wyniku akcji regularyzacyjnej w latach 2002-2004 pobyt zalegalizowało 650000 osób.

33 Country factsheet: Italy 2013. European Migration Network, s. 4: http://ec.europa.eu/ dgs/home-affairs/what-we-do/networks/european_migration_network/reports/docs/country-factsheets/15.italy_emn_country_factsheet_2013.pdf (dostęp: 11.05.2015).

${ }^{34}$ Immigration in Italy in 2013 By IDOS - Study and Research Centre, s. 1. http://www.dossierimmigrazione.it/docnews/file/2014_Scheda\%20Dossier\%20inglese.pdf (dostęp: 11.05.2015).

${ }_{35}$ Caritas e Migrantes. XXIII Rapporto sul Immigrazione 2013.Tra crisi e diritti umani. Sintesi, s. 11. Większość migrantów, bo $61,8 \%$ mieszka na Północy, 24,2\% w rejonach centralnych i tylko $14 \%$ na Południu i na wyspach - ibid., s. 12. Raport dostępny na stronie: http://www.caritasitaliana.it/home_page/area_stampa/00003960_Rapporto_Immigrazione_Caritas_e_Migrantes_2013.html (dostęp: 11.05.2015).

${ }^{36}$ Country factsheet: Italy 2013, s. 4. 
osób ${ }^{37}$. Liczba złożonych w 2013 r. wniosków o ochronę międzynarodową wynosiła 26620 i w ostatecznym rozrachunku na 23,634 decyzji kończących postępowanie 14,992 było pozytywnych (13\% aplikujących uzyskało status uchodźcy) ${ }^{38}$.

Choć imigracja do Włoch ma charakter różnorodny, to do czasu ,wiosny arabskiej" zdominowana została przez nieregularny napływ cudzoziemców przez Morze Śródziemne - w 2011 r. odnotowano wjazd ponad 62000 takich osób ${ }^{39}$. Republika Włoska w ramach współpracy z państwami pochodzenia migrantów podpisała umowy o readmisji bądź też porozumienia o współpracy z państwami afrykańskimi - Algierią, Egiptem, Libią, Marokiem i Tunezją ${ }^{40}$. Również Unia Europejska dąży do podpisywania umów o readmisji z państwami trzecimi, a także do zacieśnienia współpracy na poziomie zarządzania migracją. Przykładem takich działań na poziomie UE było podpisanie umowy w Cotonou ${ }^{41}$ i organizacja tzw. misji wyprzedzających, których celem jest nawiązanie współpracy z instytucjami państw pochodzenia odpowiedzialnymi za realizację polityki migracyjnej i rozpoczęcie dwustronnej współpracy na poziomie wykonawczym $^{42}$. Warto również wspomnieć o operacji Mare Nostrum, realizowanej przez Republikę Włoską od października 2013 r., której celem była ochrona granicy morskiej $^{43}$. Działanie te zostały zastąpione w listopadzie 2014 r. operacją Tryton kierowaną przez Agencję Frontex ${ }^{44}$.

37 Ibid., s. 6.

38 Ibid., s. 5.

${ }^{39}$ Fundamental rights at Europe's southern sea borders, FRA 2013, s. 21. Dane dotyczące liczby osób napływających do UE ilustruje tabelka dostępna w raporcie na s. 21.

${ }^{40}$ Ibid., s. 101. Definicję umów o readmisji można znaleźć w: IOM Glossary on Migration, Geneva 2004, s. 52. http://publications.iom.int/bookstore/free/IML_1_EN.pdf (dostęp: 11.05.2015).

${ }^{41}$ Umowa o partnerstwie między krajami Afryki, Karaibów i Pacyfiku a Wspólnotą Europejską i jej krajami członkowskimi z 23 czerwca 2000 r., Dz.Urz. UE z 15.12.2000, L 317 (Cotonou Agreement I). Rewizja umowy miała miejsce w 2005 i 2010 r. Więcej na ten temat: Eisele K., The external dimension of the EU's Migration Policy, Brill-Nijhoff 2014, s. 258.

${ }^{42}$ WALCZAK I. (2015), Wzmocnienie działań powrotowych poprzez inicjowanie i rozwój wspótpracy z państwami trzecimi w zakresie wykonywania umów o readmisji, w: A.M. Kosińska, P. Wojtasik (red.), Acquis Return. Doświadczenia implementacji i rozwój polityki powrotowej UE, Lublin, s. 7 (maszynopis).

${ }^{43} \mathrm{Na}$ temat operacji: http://www.marina.difesa.it/EN/operations/Pagine/MareNostrum.aspx. Zob. również: Undocumented justice for migrants in Italy. Mission report 2014, s. 5. Zgodnie z Aida Report w trakcie trwającej rok operacji udało się uratować 156362 imigrantów. Podczas operacji aresztowano również 366 osób odpowiedzialnych za przemyt osób (ibid., s. 11).

${ }^{44}$ European Commision Memo, Frontex Joint Operation 'Triton' - Concerted efforts to manage migration in the Central Mediterranean, Brussels 7.10.2014. http://europa.eu/rapid/press-release_MEMO-14-566_en.htm (dostęp: 11.05.2015). 
Problemy Republiki Włoskiej z organizacją systemu azylowego związane są przede wszystkim ze zjawiskiem napływu migrantów przez Morze Śródziemne. Pierwsze tak liczne przyjazdy miały miejsce w 1999 r. - byli to migranci przede wszystkim z Albanii, uciekający przed konfliktem w Kosowie ${ }^{45}$. W kolejnych latach (2000-2007) poziom przyjazdów imigrantów kształtował się na podobnym poziomie, nie przekraczając 24000 osób rocznie. Jednak w związku z konfliktami w Afryce Północnej, w latach 2008, 2011, 2013 i 2014 liczba osób przybywających na Półwysep Apeniński przez Morze Śródziemne gwałtownie wzrosła w 2014 r. było to ponad 65000 osób $^{46}$. Jeśli chodzi o regiony Włoch, szczególnie narażone na napływ migrantów są Sycylia (ponad 56000 osób w 2014 r.), Puglia, Calabria i Campania ${ }^{47}$.

Podstawą prawną dla udzielania ochrony międzynarodowej na poziomie krajowym jest art. 10 zd. 3 włoskiej Konstytucji, zgodnie z którym „cudzoziemiec, który w kraju pochodzenia nie ma możliwości korzystania z demokratycznych wolności gwarantowanych przez konstytucję Włoch, ma prawo ubiegać się o azyl na zasadach określonych prawem"48.

Włoski system azylowy opiera się na funkcjonującym na podstawie Legge 189/2002 systemie ochrony dla osób ubiegających się o azyl i uchodźców ${ }^{49}$. W użyciu powszechnym jest skrót nazwy (zbudowany z pierwszych liter - Sistema di protezione richedenti asilo e rifiugiati) - SPRAR. SPRAR składa się obecnie z sieci podmiotów lokalnych, zarządzany jest natomiast przez MSW. Krajowy system recepcyjny SPRAR został powiększony w związku z napływem migrantów na podstawie dekretów Ministra Spraw Wewnętrznych z czerwca i września 2013 r., które przewidywały zwiększenie liczby miejsc w ośrodkach

45 Rapporto sulla protezione internazionale in Italia 2014, Caritas Italiana, s. 8. http://www. caritasitaliana.it/pls/caritasitaliana/v3_s2ew_consultazione.mostra_pagina?id_pagina=5396 (dostęp: 11.05.2015).

${ }^{46}$ Rapporto sulla protezione, s. 8.

${ }^{47}$ Ibid., s. 9. Jeśli chodzi o narodowość osób przypływających, to w 2014 r. były to Erytrea, Syria, Mali, Gambia i Nigeria. W 2013 r. pierwsze kraje pochodzenia, jeśli chodzi o przyznanie statusu uchodźcy, były to: Nigeria, Pakistan, Somalia, Erytrea i Afganistan.

${ }^{48}$ Undocumented justice for migrants in Italy, s. 10. Oficjalne tłumaczenie Konstytucji dostępne na stronie: https://www.senato.it/documenti/repository/istituzione/costituzione_inglese.pdf (dostęp: 11.05.2015).

${ }^{49}$ Rapporto sulla protezione, s. 13. Poprzednikiem SPRAR był Narodowy Program Azylu (Programma Nazionale Asilo - PNA), stanowiący forum współpracy pomiędzy regionami i III sektorem, powołany do życia w 2001 r. na podstawie porozumienia pomiędzy włoskim MSW, UNHCR oraz ANCI (Associazione nazionale dei comuni italiani). 
w ciągu trzech lat (2014-2016) do $20000^{50}$. Kolejnym działaniem w związku ze zwiększającą się liczbą migrantów było stworzenie specjalnych miejsc recepcyjnych, do czego zostały zobowiązane lokalne prefektury - zgodnie z planem Krajowej Grupy Roboczej, do grudnia 2014 r. liczba osób umieszczonych w takich centrach wynosiła prawie $35000^{51}$.

W systemie włoskim wyróżnić można kilka rodzajów ośrodków recepcyjnych dla osób ubiegających się o ochronę międzynarodową - są to ośrodki recepcyjne dla imigrantów, w których udzielana jest pierwsza pomoc i przeprowadzana identyfikacja cudzoziemca (zwane w skrócie CDA/CPSA), ośrodki recepcyjne dla osób ubiegających się o ochronę międzynarodową (tzw. CARA - Centri accoglienza richiedenti asilo), ośrodki detencyjne, gdzie przebywają osoby, które złożyły wniosek statusowy po wydaniu wobec nich decyzji zobowiązującej do powrotu (CIE) oraz ośrodki prowadzone w ramach SPRAR (zazwyczaj przeznaczone dla mniejszej liczby migrantów) ${ }^{52}$. Największe znaczenia dla funkcjonowania systemu azylowego ma organizacja CARA i CDA - większość $\mathrm{z}$ nich usytuowana jest $\mathrm{w}$ południowych regionach Włoch ${ }^{53}$.

Włochy do momentu wejścia w życie konwencji dublińskiej (1997) były przede wszystkim krajem tranzytowym dla migrantów ${ }^{54}$. Jednak już w 1998 r. rozpatrzono we Włoszech 13100 wniosków statusowych - co stanowiło zasadniczy wzrost w porównaniu z 1890 wnioskami rok wcześniej. Szczególny moment stanowiło podpisanie umowy z Libią w 2009 r., w wyniku której dochodziło do systematycznego zawracania osób poszukujących ochrony. W związku z utrudnianiem aplikowania o status uchodźcy oraz niebezpieczeństwem naruszenia art. 3 EKPCZ, zawrócenia takie zostały uznane za niezgodne z prawem na mocy wyroku Trybunału w sprawie Hirsii Jaama ${ }^{55}$.

${ }^{50}$ Asylum Information Database, Country Report, Italy, AIDA 2015, s. 12. Zgodnie z danymi raportowymi na styczeń 2015 r., Włochy dysponowały 19900 miejscami. http://www.asylumineurope.org/reports/country/italy (dostęp: 11.05.2015).

${ }^{51}$ Asylum Information Database, s. 12. Ponadto zwiększona została liczba komisji regionalnych odpowiedzialnych za rozpatrywanie wniosków azylowych.

52 The Organisation of Reception Facilities for Asylum Seekers in different Member States, EMN Focussed Study 2013, s. 1-2. Raport dostępny na stronie: http://ec.europa.eu/dgs/home-affairs/what-we-do/networks/european_migration_network/reports/studies/results/index_en.htm (dostęp: 15.05.2015).

${ }^{53}$ Rapport sullo stato dei diritti umani negli istituti penitenziari e nei centri do accoglienza e trattenimento per migrant in Italia, Senato della Reppublica 2012, s. 112.

${ }^{54}$ Asylum procedure and reception centres in Italy, Report on the situation of asylum seekers, refugees and persons under subsidiary or humanitarian protection, with focus on Dublin returnees, Berne-Oslo 2011, s. 12. Raport dostępny na stronie: http://www.refworld.org/docid/4e2699b92. html (dostęp: 15.05.2015).

55 Wyrok Europejskiego Trybunału Praw Człowieka z 23.02.2012 r. w sprawie Hirsi Jamaa i inni przeciwko Włochom, skarga nr 27765/09. 
Transfery dublińskie są przeprowadzane we Włoszech przez Kwesturę Policji w ramach odpowiedzialnej za nie jednostki Dublin. W związku z możliwością zastosowania klauzul dyskrecjonalnych włoska Rada ds. Uchodźców zwróciła się z wnioskiem do kompetentnych jednostek o wstrzymanie powrotów cudzoziemców do Grecji po orzeczeniu w sprawie M.S.S. ${ }^{56}$ - jednostka dublińska nie zajęła oficjalnego stanowiska w tej sprawie, jednak przekazania do Grecji należały już w 2011 r. do rzadkości. Podobnie w stosunku do powrotów na Węgry oraz na Maltę, Ministerstwo Spraw Wewnętrznych nie zajęło oficjalnego stanowiska, mimo trendu, zgodnie z którym unika się odsyłania cudzoziemców do tych krajów ${ }^{57}$.

\section{ORZECZENIE W SPRAWIE TARAKHEL}

Wyrok ETPCZ w sprawie Tarakhel, wydany 4 listopada 2014 r., opierał się na zarzucie skarżącego, że jego zawrócenie do Włoch, na podstawie przepisów rozporządzenia dublińskiego, skutkować będzie nieludzkim traktowaniem i tym samym naruszeniem art. 3 Konwencji oraz naruszeniem art. 8 gwarantującego ochronę życia rodzinnego.

Sprawa dotyczyła rodziny afgańskiej, która mieszkała w Iranie i następnie zdecydowała się przez Turcję przedostać do Włoch drogą morską. Rodzina przybyła do Calabrii w czerwcu 2011 r., złożyła wniosek o status uchodźcy i poddana została procedurze daktyloskopii oraz identyfikacji, następnie skierowana do ośrodka recepcyjnego w Stignano, potem zaś do CARA w Bari ${ }^{58}$. Zdaniem skarżących warunki w ośrodku były fatalne i panowała tam przemoc, w związku z tym po kilku dniach zdecydowali się opuścić Puglię i udali się do Austrii, gdzie ponownie złożyli wniosek statusowy, który został odrzucony w związku z wcześniejszym pobraniem od nich danych daktyloskopijnych i umieszczeniem ich w systemie Eurodac ${ }^{59}$.

${ }^{56}$ Asylum Information Database, s. 28.

${ }^{57}$ Ibid. Przeciwko transferom do tych krajów wypowiadały się w orzeczeniach sądy administracyjne Włoch. Zarzutem w raporcie AIDA był brak dostępu dla cudzoziemców do podstawowych informacji na temat procedury zawrócenia do kraju pierwszego wjazdu - sytuacja ta uległa poprawie w styczniu 2014 r. wraz z wejściem w życie rozporządzenia Dublin III. Na temat orzecznictwa włoskich sądów w sprawach dublińskich - ibid., s. 34.

${ }^{58}$ Na temat warunków złych warunków panujących w CARA w Bari przeczytać można również w Newsletterze PICUM z 17.03.2015 r., http://picum.org/en/news/bulletins/46429/ (dostęp: 11.05.2015).

59 Pkt 11 wyroku. 
W listopadzie 2011 r. skarżący złożyli wniosek o status uchodźcy w Szwajcarii, który decyzją kompetentnych władz krajowych został odrzucony w styczniu 2012 r. i wobec rodziny została podjęta decyzja o zawróceniu do Włoch jako kraju pierwszego wjazdu do UE. Apelacja rodziny Tarakhel od decyzji została odrzucona, w marcu 2012 r. zaś skarżący złożyli ponowny wniosek o status, który również został odrzucony ${ }^{60}$. W maju 2012 r. rodzina Tarakhel złożyła skargę do ETPCZ, prosząc o zastosowanie środka tymczasowego w postaci zakazu wydalenia ze Szwajcarii do momentu rozpatrzenia sprawy przez Trybunał, do czego ETPCZ się przychylił ${ }^{61}$.

Analizując sprawę, Trybunał powołał się na orzecznictwo sądów krajowych, w tym na wyroki Federalnego Sądu Administracyjnego Szwajcarii - zgodnie z orzeczeniem z 18 października 2013 r. Sąd uznał, że Szwajcaria powinna zastosować klauzulę dyskrecjonalną z rozporządzenia dublińskiego i wstrzymać się od zawrócenia rodziny somalijskiej do Włoch ${ }^{62}$.

Trybunał zwrócił również uwagę na fakt, że gwarancje prawne dotyczące zakazu nieludzkiego traktowania obecne są również w prawie europejskim, tj. w Karcie praw podstawowych ${ }^{63}$, a także w linii orzeczniczej ETPCZ (sprawa M.S.S) i TSUE (sprawa N.S).

Co warto podkreśli, Szwajcaria nie jest członkiem Unii Europejskiej, ale uczestniczy w Strefie Schengen w związku z umową stowarzyszeniową z 2004 r. $^{64}$

Analizując zarzuty stron, Trybunał wziął również pod uwagę istotne przepisy rozporządzenia dublińskiego dotyczące ochrony najlepszego interesu dziec$\mathrm{ka}^{65}$, wymiany niezbędnych informacji przed dokonaniem transferu ${ }^{66}$, w tym danych dotyczących zdrowia migrantów ${ }^{67}$. Ponadto Trybunał przytoczył art. 33

\footnotetext{
${ }^{60}$ Pkt 19 wyroku.

${ }^{61}$ Pkt 21 wyroku,

62 Sprawa E-1574/2011 of 18 October 2013.

${ }_{63}$ Art. 4, 18, 19, 24 Karty praw podstawowych Unii Europejskiej, Dz.U. C 326/02
} z 26.10.2012 r.

${ }^{64}$ Umowa z 26 października 2004 r. zawarta przez Unię Europejską, Wspólnotę Europejską i Konfederację Szwajcarską w sprawie włączenia Konfederacji Szwajcarskiej we wprowadzanie w życie, stosowanie i rozwój dorobku Schengen, Dz.Urz. UE L 53 z 27.02.2008 r., zob. również Szachoń-Pszenny A. (2014), Polska jako państwo członkowskie strefy Schengen na tle innych typów uczestnictwa $w$ acquis Schengen, w: A. Szachoń-Pszenny, A. Kuś (red.), Wpływ acquis communautaire i acquis Schengen na prawo polskie - doświadczenia perspektywy, t. 2: 15 lat acquis Schengen w prawie Unii Europejskiej, Lublin, s. 301 i n. Rozporządzenie Dublin III weszło w życie w stosunku do państw członkowskich 1 stycznia 2014 r., wobec Szwajcarii zaś obowiązuje od 7.03.2014 r.

\footnotetext{
${ }^{65}$ Art. 6 rozporządzenia 604/2013.

${ }^{66}$ Art. 31. Wymiana ta odbywa się obecnie poprzez sieć elektroniczną „DubliNet”.

${ }^{67}$ Art. 32 rozporządzenia 604/2013.
} 
dublińskiego rozporządzenia dotyczący mechanizmu wczesnego ostrzegania, gotowości i zarządzania kryzysowego - zgodnie z nim, w przypadku, gdy dane państwo członkowskie może być narażone na przeciążenie systemu azylowego, Komisja może skierować zalecenia i wezwać takie państwo do opracowania we współpracy z EASO działań zapobiegawczych ${ }^{68}$.

Trybunał szczegółowej analizie poddał również funkcjonowanie włoskiego systemu azylowego. Powołując się na uzasadnienie orzeczenia w sprawie Mohammed Hussain, Trybunał scharakteryzował planowane zmiany w systemie ośrodków recepcyjnych. Cennym źródłem dla Trybunału okazał się również raport i rekomendacje UNHCR wobec systemu ochrony uchodźców we Włoszech $^{69}$. W dokumencie zwrócono m.in. uwagę na problem oczekiwania na rejestrację wniosków statusowych, która trwa niekiedy nawet kilka tygodni. Ponadto procedura dublińska ustalania państwa odpowiedzialnego trwa we Włoszech nawet do 24 miesięcy, wpływając tym samym na kondycję i samopoczucie migrantów. Podkreślono również fakt, że w związku ze znaczącym napływem migrantów do Włoch od 2011 r. utworzona została Krajowa Grupa Koordynacyjna, kierowana przez Ministra Spraw Wewnętrznych. Na uwagę zasługuje również fakt, że podczas transpozycji poprzedniej wersji dyrektywy recepcyjnej regulacje włoskie były bardziej korzystne od tych przewidzianych na poziomie UE. Kolejnym źródłem, na jakie powołał się Trybunał w analizie systemu azylowego Włoch, był raport komisarza ds. ochrony praw człowieka Rady Europy z wizyty odbytej w czerwcu 2012 r. ${ }^{70}$ oraz dane przedstawione przez IOM ${ }^{71}$.

Trybunał przeanalizował również istotne z punktu widzenia sprawy orzecznictwo sądów państw członkowskich ${ }^{72}$. Szczególną uwagę poświęcił orzeczeniu Sądu Najwyższego Zjednoczonego Królestwa z 14 lutego 2014 r., w którym skład orzekający uznał, że bez względu na fakt istnienia systemowych naruszeń w systemie azylowym Włoch, sądy są zobowiązane do zbadania w każdej spra-

${ }^{68}$ Art. 33 rozporządzenia 604/2013.

${ }^{69}$ Recommendations of the Office of the United Nations High Commissioner for Refugees on important aspects of refugee protection in Italy - zob. pkt 47 wyroku.

70 Report by Nils Muižnieks, Commissioner for Human Rights of the Council of Europe, published on 18 September 2012, following his visit to Italy from 3 to 6 July 2012 (Com$\mathrm{mDH}(2012) 26)$.

${ }^{71}$ Information provided by the International Organization for Migration in a press briefing note of 28 January 2014 - zob. pkt 50 wyroku.

72 Przykładowo w wyroku z 9.07.2013 r. (no. 7 K 560/11.F.A) sąd administracyjny we Frankfurcie stwierdził, że „Sąd jest przekonany, że systemowe braki w organizacji system recepcyjnego we Włoszech sanowią podstawę do uznania, że aplikujący o ochronę w przypadku zawrócenia do Włoch, będzie poddany realnemu ryzyku nieludzkiego traktowania w rozumieniu art. 4 Karty praw podstawowych". 
wie, czy zawrócenie cudzoziemców do Italii będzie się wiązało z ich traktowaniem sprzecznym z przepisami Konwencji ${ }^{73}$.

Rozpatrując zasadność skargi, Trybunał zbadał najpierw ryzyko nieludzkiego i poniżającego traktowania w przypadku zawrócenia do Włoch. Skarżący Tarakhel w postępowaniu powołał się na liczne dokumenty organizacji międzynarodowych i pozarządowych, informujące o lukach i problemach włoskiego systemu azylowego ${ }^{74}$, zarzucając m.in. włoskim służbom przewlekłość procedury identyfikacyjnej, ograniczone możliwości przyjmowania dużych liczb azylantów w ośrodkach recepcyjnych, a także panujące tam warunki ${ }^{75}$. W odpowiedzi na zarzuty rząd włoski uznał je za niezasadne, ostatecznie jednak potwierdzając opinię skarżących, że w ośrodku w Bari dochodziło do aktów przemocy podczas ich pobytu ${ }^{76}$.

Rządy Szwecji, Danii, Norwegii i Zjednoczonego Królestwa zwróciły uwagę, że UNHCR w swoich rekomendacjach nie wypowiadał się na temat wstrzymania zawróceń do Włoch wobec grup tzw. wrażliwych i narażonych na naruszenia ( $w$ tym rodzin $\mathrm{z}$ dziećmi ${ }^{77}$. Organizacje pozarządowe AIRE Centre, ECRE i Amnesty International podkreśliły jednak, że transfer dzieci może być dokonany jedynie w sytuacji, gdy leży to w najlepszym interesie dziecka ${ }^{78}$.

Rozważając możliwość naruszenia art. 3 Konwencji w przypadku zawrócenia rodziny Tarakhel do Włoch, skład orzekający powołał się na dotychczasową linię orzeczniczą, m.in. sprawę M.S.S. dotyczącą stwierdzenia ryzyka nieludzkiego traktowania w przypadku zawrócenia do Grecji. Trybunał podkreślił również, że kluczową kwestią dla sprawy jest interes i dobro dziecka. Mimo istniejących braków w organizacji systemu azylowego we Włoszech, Trybunał orzekł, że obecna sytuacja we Włoszech nie może być w żadnym wypadku porównana do sytuacji Grecji z momentu wydania orzeczenia w sprawie M.S.S. Biorąc jednak pod uwagę sytuację rodzinną skarżącego, Trybunał uznał, że władze Szwajcarii powinny uzyskać indywidualne gwarancje od władz Włoch, że dzieci będą traktowane stosownie do ich wieku oraz że rodzina nie zostanie rozdzielona. W przeciwnym razie takie zawrócenie narażałoby skarżącego na nieludzkie traktowanie $\mathrm{z}$ art. 3 Konwencji.

${ }^{73}$ Pkt 52 wyroku.

74 Pkt 57 wyroku

75 Pkt 66 wyroku.

76 Pkt 86 wyroku.

77 Pkt 79 wyroku.

${ }^{78}$ Pkt 85 wyroku. 
Częściowo odrębną opinię w sprawie przedstawili sędziowie Casadevall, Berro-Lefevre oraz Jaderblom ${ }^{79}$. Zwrócili oni uwagę, że mimo braków we włoskiej procedurze azylowej, nie ma powodów by wstrzymywać tam powroty na podstawie konwencji dublińskiej. Zdaniem sędziów nawet warunki podobne do tych panujących w CARA w Bari nie stanowiłyby powodu wstrzymania powrotu rodziny Tarakhel. Sędziowie podkreślili jednocześnie, że rodzinie zawsze, w przypadku realnego naruszenia, przysługiwałaby skarga przeciwko Republice Włoskiej na podstawie Konwencji.

\section{KONKLUZJE}

W związku ze wzmożonym napływem migrantów przez południowe granice Unia Europejska staje przed kluczowym wyzwaniem zwiększenia z jednej strony bezpieczeństwa migrantów, z drugiej zaś skutecznej ochrony granic. Istotną kwestią pozostaje również zapewnienie sprawnego działania systemów azylowych w państwach pozostających pod szczególną presją migracyjną - tj. w Grecji i we Włoszech. Odpowiedzią na aktualną sytuację na Morzu Śródziemnym był nadzwyczajny szczyt Rady Europejskiej z 23 kwietnia 2015 r., na którym przedstawiciele państw członkowskich zobowiązali się do zintensyfikowania działań w ramach operacji Tryton, wzmocnienia współpracy z krajami pochodzenia migrantów, a także działań na rzecz wzmocnienia solidarności pomiędzy państwami członkowskimi w zarządzaniu migracjami ${ }^{80}$. Włochy korzystają już ze wsparcia EASO w postaci AST, jednak konieczne są dalsze działania na rzecz polepszenia warunków w tamtejszych ośrodkach recepcyjnych.

Wydaje się, że orzeczenia w sprawie Tarakhel stanowiło wyjątek od ugruntowanej linii orzeczniczej Trybunału w sprawach dublińskich ze względu na szczególną sytuację rodzinną skarżącego oraz potrzebę ochrony praw dziecka i jedności rodziny. W kolejnym wyroku dotyczącym zawrócenia do Włoch A.M.E przeciwko Holandii - Trybunał uznał skargę dotyczącą nakazu zawrócenia cudzoziemca do Włoch za niedopuszczalną ${ }^{81}$. Sprawa dotyczyła młodego Somalijczyka, który po otrzymaniu ochrony uzupełniającej we Włoszech, złożył wniosek o status uchodźcy w Holandii. W związku z tym, że na podstawie przepisów rozporządzenia dublińskiego powinien być on zawrócony do Włoch,

79 Strona 53 pełnej wersji wyroku.

${ }^{80}$ Special meeting of the European Council, 23 April 2015 - statement, http://www.consilium.europa.eu/en/press/press-releases/2015/04/23-special-euco-statement/.

${ }^{81}$ Wyrok Europejskiego Trybunału Praw Człowieka z 13.01.2015 r. w sprawie A.M.E przeciwko Holandii, skarga nr 51428/10. 
cudzoziemiec twierdził, że powrót do Italii stworzy ryzyko nieludzkiego traktowania. Trybunał stwierdził, że skarżący nie przedstawił żadnych dowodów na istnienie takiego ryzyka, jego sytuacja osobista zaś jest zupełnie inna niż skarżącego Tarakhel, ze względu na brak rodziny oraz osób zależnych pozostających pod jego opieką.

Istota wyroku $\mathrm{w}$ sprawie Tarakhel polega $\mathrm{z}$ jednej strony na zwróceniu uwagi opinii publicznej na problemy, jakich doświadczają Włochy w związku z napływem migrantów i osób poszukujących ochrony międzynarodowej, z drugiej zaś wyrok potwierdza konieczność rozważenia najlepszego interesu dziecka w każdej sprawie, jakiej interes małoletniego dotyczy.

Streszczenie

\section{ZNACZENIE WYROKU W SPRAWIE TARAKHEL PRZECIWKO SZWAJCARII WOBEC PROBLEMU NAPŁYWU OSÓB POSZUKUJĄCYCH OCHRONY MIĘDZYNARODOWEJ DO REPUBLIKI WŁOSKIEJ}

Celem niniejszego artykułu jest analiza wyroku Europejskiego Trybunału Praw Człowieka z 4 listopada 2014 r. w sprawie Tarakhel przeciwko Szwajcarii, w którym Trybunał uznał, że zawrócenie migrantów ubiegających się o status uchodźcy ze Szwajcarii do Włoch, jako państwa właściwego do rozpatrzenia ich wniosku statusowego, może naruszyć gwarancje z art. 3 i 8 Europejskiej konwencji o ochronie praw człowieka i podstawowych wolności. Uzasadniając wyrok, Trybunał oparł się w szczególności na argumentach dotyczących problemów, z jakimi boryka się Republika Włoska w organizacji systemu azylowego, w tym funkcjonowaniu ośrodków recepcyjnych. Tym samym Włochy stały się kolejnym państwem, które zdaniem Trybunału, nie zapewnia warunków godnego i humanitarnego rozpatrzenia wniosków o status uchodźcy składanych przez obywateli państw trzecich.

Słowa kluczowe: Europejski Trybunał Praw Człowieka; azyl; status uchodźcy, Europejska konwencja o ochronie praw człowieka i podstawowych wolności; Sprawa Tarakhel przeciwko Szwajarcii. 


\section{Summary}

\section{MEANING OF THE JUDGEMENT OF ECHR IN TARAKHEL CASE IN RELATION WITH THE FLOW OF ASYLUM - SEEKERS TO THE REPUBLIC OF ITALY}

The aim of the present paper is analysis of the European Court of Human Rights Judgment in case Tarakhel v Switzerland (judgment of $4^{\text {th }}$ November 2014) where the Tribunal found that sending back the applicant family to Italy constituted the risk of violation of article 3 and article 8 of the Convention. In justification of the above mentioned decision the Court indicated the problems that Italy meets in organization of asylum system and reception centers. The article describes also the current migratory situation of Italy, national legal framework of asylum system and its implementation. Moreover the paper gives the comparative perspective, presenting the judgments of MS' as well as international courts decisions considering the returns of asylum seekers under Dublin Regulation's provisions.

Keywords: migration to Italy, Dublin Regulation, asylum procedure, reception system, irregular migrants, Tarakhel case.

\section{BIBLIOGRAFIA:}

Castles S., Miler M.J. (2009), The Age of Migration, New York.

FAKIOLAS R. (2010), Italy and Greece: from emigrants to immigrants, w: R. Cohen (ed.), The Cambridge Survey on World Migration, Cambridge University Press.

Gierowski J.A. (2003), Historia Wtoch, Wrocław.

KosińsKa A.M. (2015), Działalność FRONTEX w kontekście ochrony problematyki ochrony praw migrantów nieregularnych w Unii Europejskiej, w: A. Kuś, A. Kosińska, A. Szachoń-Pszenny (red.), Agencja FRONTEX w strefie Schengen. 10 lat doświadczeń, Lublin.

Szachoń-Pszenny A. (2014), Polska jako państwo członkowskie strefy Schengen na tle innych typów uczestnictwa $w$ acquis Schengen, w: A. Szachon-Pszenny, A. Kuś (red.), Wptyw acquis communautaire $i$ acquis Schengen na prawo polskie - doświadczenia perspektywy, t. 2: 15 lat acquis Schengen w prawie Unii Europejskiej, Lublin.

WalczaK I. (2015), Wzmocnienie działań powrotowych poprzez inicjowanie i rozwój wspótpracy z państwami trzecimi w zakresie wykonywania umów o readmisji, w: A.M. Kosińska, P. Wojtasik (red.), Acquis Return. Doświadczenia implementacji i rozwój polityki powrotowej UE, Lublin. 
